European Journal of

Philosophy, Culture and Religious Studies (EJPCR)

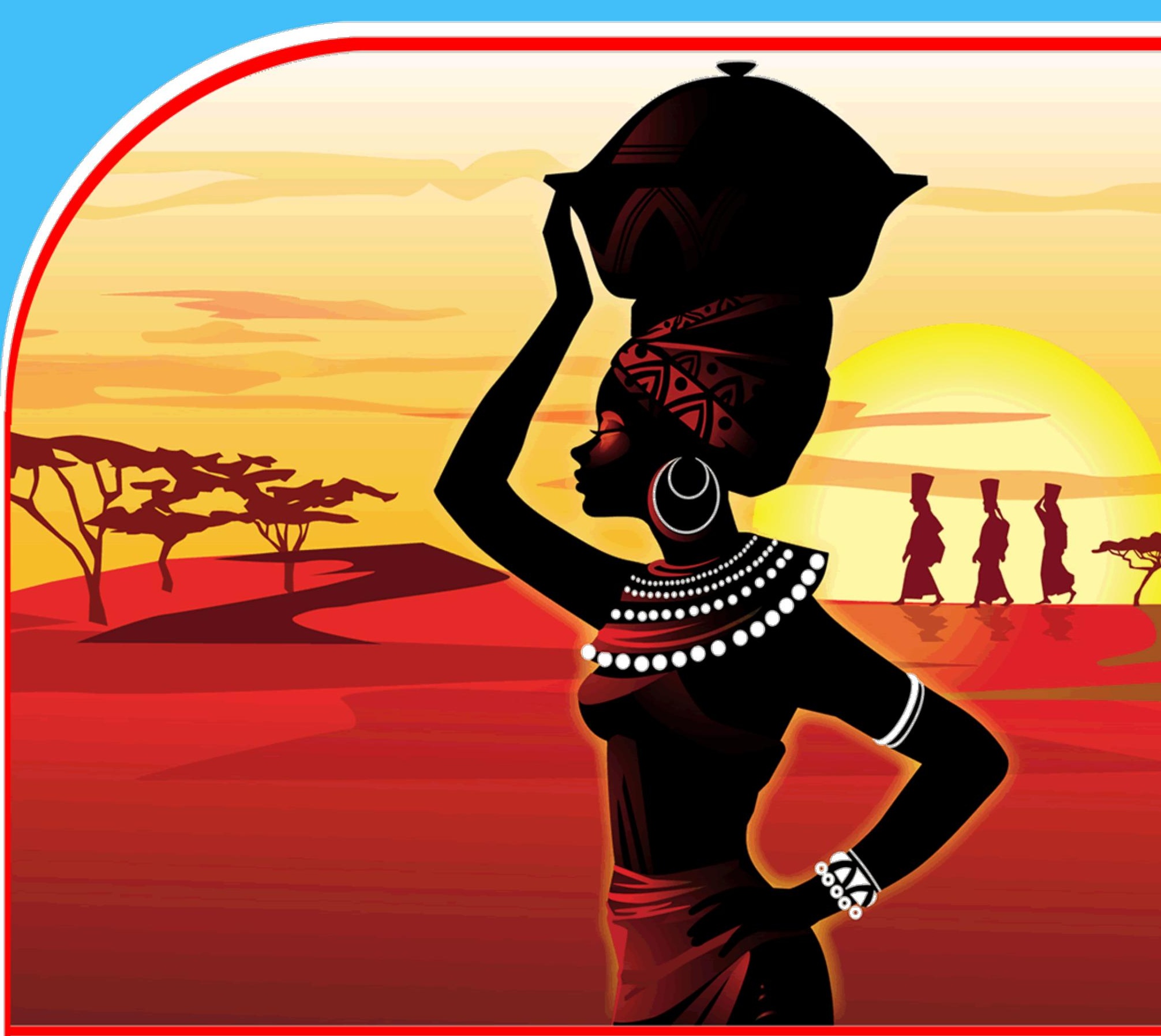

THE SUCCESS OF CHURCH OF GOD-KENYA PROJECTS IN POVERTY ALLEVIATION IN EMUHAYA DISTRICT, WESTERN KENYA

Obwoge Hezekiah, Dr. K. Onkware, Dr. C. Iteyo 


\title{
THE SUCCESS OF CHURCH OF GOD-KENYA PROJECTS IN POVERTY ALLEVIATION IN EMUHAYA DISTRICT, WESTERN KENYA
}

\author{
1*Obwoge Hezekiah \\ Post Graduate Student, Maseno University \\ *Corresponding Author's E-mail: obwogezek@gmail.com \\ ${ }^{2}$ Dr. K. Onkware \\ Lecturer, Masinde Muliro University of Science and Technology \\ ${ }^{2}$ Dr. C. Iteyo \\ Lecturer, Maseno University
}

\begin{abstract}
Purpose: The purpose of the study was to examine the success of CoG-Kenya projects in poverty alleviation in Emuhaya District, Western Kenya

Methodology: This study was a cross-sectional research that sought to give an examining and descriptive scrutiny of the CoG-K's activities in Emuhaya District of Western Kenya. This study sampled a total of 312 respondents (1 Bishop, 1 General Secretary, 1 General Assembly Trustee, 1 General Assembly Treasurer, 16 Directors, 282 Pastors, and 10 Elders) through purposive sampling method. Oral interviews, questionnaire methods and focus group discussion were used to collect data from the respondents. Observation method was used to validate the information obtained through oral interviews and questionnaires. Secondary data was sourced from published and unpublished literature. Data was analyzed using the theological method of induction (TMI).

Results: The study proved that the CoG-K has a role to play through her programs like Sisi kwa Sisi, Child Development Centres, Health care Units and education, thus these institutions make a significant contribution to sustainable development in Emuhaya District and are useful instruments for spearheading alleviation of poverty in the said district. The CoG-K's development is founded upon a spirituality of mutual sustenance and transformation through its concern for the adherents' struggle with poverty. This study found out that faith activities and the related projects implicitly advance the poverty alleviation cause, thus all development revolves around spirituality. From this perspective the CoG-K has the responsibility to engage in all aspects of development within spirituality as the foundation of such engagement.
\end{abstract}

Unique contribution to theory, practice and policy: The study recommends that development experts, theologians, policy makers and practitioners should cultivate long-term relationship with the church in general and the CoG-K in particular so as implement policy for development consequently alleviating poverty.

Keywords: CoG-K projects, poverty alleviation, Emuhaya District, Western Kenya 
European Journal of Philosophy, Culture and Religious Studies

ISSN 2520-4696 (Online)

Vol.1, Issue 2 No.1, pp1-24, 2017

www.ajpojournals.org

\subsection{INTRODUCTION}

\subsection{Background of the Study}

The present economic situation of Africa in general and Kenya in particular appears to be characterized by poverty and suffering which form relatively high levels of material deprivation. Poverty is a state of human deprivation with regard to personal income, clothing, housing, health care, education, sanitary facilities and human rights (World Bank, 2001). Poverty or being poor in the church's understanding commonly means a state of or lack of what ought to be (Myers, 2000). In both the Bible's Old and New Testament, the poor are the oppressed by both socio-cultural and economic conditions. They are the deprived and the needy beggars. Thus, the theological basis for the option for the poor in the church is that the poor possess a sacramental function in the society (Ibid.).

In Kenya, the 2007 Human Development (HD) Survey showed that the people living in abject poverty constituted $56.3 \%$ of the Kenyan population, and that the situation was deteriorating further as it has continued to rise from 30\% in early 1990's to 56\% by 2007 (MDG Centre, 2009). Over 65\% of the people living in Emuhaya District where the Church of God - Kenya herein referred to as CoG-K is the most dominant denomination, live below the poverty line and are food poor (ESDP, 2008). This means that more than a half of the population in Emuhaya District is in some state of poverty. Whereas poverty, religion and corruption may account for some of this plight, many of the poor are victims of natural disasters, famine or drought. Farmers on the other hand, often cannot make an adequate living from their small and infertile land. In addition to suffering, sheer lack of income, the poor are often uneducated and afflicted with physical sickness (Ibid.).

Furthermore, the Kenyan situation could rightly be cited as the best example of glaring disparity between the economically empowered on one side and the marginalized masses on the other. The wealthy have access and control of the market, whereas the poor remain at the mercy of the market dictates even where their own produce is concerned. A report by the Society for International Development (2004) revealed that only a tenth of the 30 million Kenyan controlled the nation's resources and income and that 42 percent of the total wealth of the country is concentrated in the hands of the 10 percent of the population (Galgalo, 2005). This implies that a tenth of the population is gobbling nearly half of the available resources.

In recent history, there has been an inclination to look at development almost entirely in economic terms (Ogot, 1999). Although very important, economics cannot be relegated to the deepest levels of life. The 2007 United Nations Development Program's (UNDP) report on Kenya shows that despite an economic growth rate of 5.8 percent, 50 percent of Kenyans lived below the poverty line (Zacharia, 2007). According to Zacharia (2007: 45):

Compared to the year 2004, human poverty has increased marginally in all provinces. 16 million Kenyans are living on less than a dollar a day, while 18.9 million can hardly afford a meal with more than a dollar at their disposal. The gap between the rich and the poor also continue to widen. Poorer people have little or no hope of bringing up a child to the age where they can benefit from free primary education introduced by the government in 2003, let alone taking them to secondary school.

The emerging crisis has prompted the continuing search for appropriate approach to, and strategies for solving the problem. Poverty alleviation has been the subject of subsequent 
National Development Plans, Session Papers, Presidential Commissions, Task Forces, and studies in Kenya. The large range of contributions reflects the pressure on the Government to find solutions to the persistence of poverty in Kenyan society. However the government of Kenya on its part has not sufficiently addressed these needs due to increasing national population growth and the concurrent costs (EDSP, 2008). This inadequacy has been greatly felt in Emuhaya District because of its high density as compared to other rural areas in Kenya (Ibid.). It is in this process of taking initiative in development that existing churches in Emuhaya District have played role in development.

Presently in Emuhaya District are a wide range of churches which are known to actively take part in human development through its agencies such as Compassion International, Youth Empowerment Programs and World Vision. These churches include the Anglican Church of Kenya, Church of God in Kenya, Pentecostal Assemblies of God, Coptic Church, Israeli Nineveh Church, African Interior Church, Salvation Army, Revival Church (CoG-K, 2007), just to mention a few. While acknowledging the role played by these churches in both spiritual and social-economic development, the present work delves its attention to the role played by the CoG-K in poverty alleviation to the populace in Emuhaya District. The Emuhaya District has a population of about 250,000 inhabitants according to the 2009 population's projections (EDP, 2010). Currently, the birth rate is estimated at $3.5 \%$ per annum (Ibid.). Nevertheless, poverty is a complex phenomenon that cannot be eradicated solely by politics, economic policies and financial investments. It is a social construct that cannot be limited to mere economic growth. In order to be authentic, it must be integral; that is, it has to promote the good of each individual and the whole person. Material and spiritual values must be brought together (Pope Paul VI, 1967).

Accordingly, the existing challenges in relation to the various dimensions of poverty require an understanding that poverty can be fought from many fronts, which include using religion. We cannot ignore the fact that religion is an economic institution as it participates in the economy and is an economic 'force' as it influences various economic activities. Today, religion is believed to seep into all aspects of life in the society including economic aspects (Mbiti, 1969). It is viewed as the most effective stimulus for economic growth and social change in general. As stated, the economy is one of the society's most important institutions and religion is in a continuous reciprocal and interdependent relationship with the economy. Although religion is often viewed as a semi-autonomous social system paralleling other institutions, it is itself in various ways part of the inclusive economic system of the society.

Poverty is a major concern of the church, and countless poverty alleviation programs and campaigns have been developed over time, across the regions. Poverty is defined as having numerous manifestations and characteristics that include low and unreliable income, poor health, and low levels of education, insecurity, disempowerment and isolation from the mainstream of the economic development (Cavanaugh, 2008). These characteristics are also referred to as indicators of measuring poverty (Ibid.). The biblical word on the relation of the community of faith to poverty is clear and unambiguous because God identifies himself with the poor, so too the community of faith is called to special concern for these persons.

Historically, many scholars, policy makers, and practitioners working broadly in programs aimed at poverty alleviation are in agreement that development coincides with religious vision in viewing history as a process of salvation (Tarino, 2005; Bryant, 1999; Sinclair, 
1980). Religions teach people to believe that happiness is either in the present or in the future and compels those who abide in it to act in a particular manner (Ibid.). In consequence religion performs the following role:

Contributes to the advancement of knowledge and commitment; such an influence is vital in fashioning values system. The spirit of commitment and creativity, as necessary components of wealth creation, arise from inside the person. Such convictions influence the material well being of individuals and communities. Economic prosperity cannot be achieved without taking into account the power of the human spirit and determination (Tarino, 2005:40).

One's belief makes a difference in the way of organizing one's life and in the perception of the good. Beliefs allow certain conditions and thinking under which the desired values could be unfolded and thereby effect action. Beliefs structure relationship between people and affect the destiny of human life (Ibid.). Within a religious culture, one finds that the way of life, the behavior patterns, the whole meaning of existence is knit together by reference to God, to the deity - to the 'Supreme Being'. Consequently, religion and life are intimately connected, and the proper action and behavior is that which is pleasing to God and what is commanded by God.

Evidently, the important place of spirituality in human development has been acknowledged (Gumo-Kurgat, 2004; Bryant, 1999; Nyaundi, 2003; Vinay, 2005). Secular groups involved in development are beginning to take seriously the religions of communities with whom they work. Scholars are seeking for ethics and morality in development strategies. Therefore, true development be it Christian or non-Christian, requires addressing the spiritual, because it is not possible to alleviate poverty without the spiritual facet. It is in this regard that the church and Christian organizations have made concerted attempts towards answering the cries of the poor in the society. This contribution of the church in alleviating poverty is likely to be enhanced by the fact that Christianity in Africa is growing greatly. This study aims at assessing the role of the CoG-K in alleviating poverty in Emuhaya District of Western Kenya.

\subsection{Problem Statement}

Poverty is a widespread phenomenon that is of interest to all stakeholders of the development processes including the Church of God in Kenya (CoG-K). Documents of earlier studies have focused on the economic systems while underestimating the power and influence of religion in the eradication of poverty; thus, relegating religion to a matter of spiritual significance. Emuhaya District experiences very high poverty levels that stand at $65 \%$ of the total population of Kenya (GoK, 2010; KNBS, 2010; ESDP, 2008). Furthermore, 52.3\% of the households in the district live below poverty levels. Thus, the district's contribution to national poverty is 3\% (Ibid.). However, it is evident that economic systems alone to date have been inadequate and the growth of poverty has not been reversed (Speckman, 2001; Ogot, 1999; Nandy, 1998). People do not live by economics or science and technology alone. Thus, the role of religion in poverty eradication has not been studied yet human spirit and determination are cornerstone for poverty alleviation and wealth creation.

Christians believe that the religious perspective in development has to be prominent in dealing with human beings, especially in an attempt to improve the quality of the human life. This view is not only based on the belief that human beings are created in God's "image and likeness" (Genesis 1:2) but also on the theological view, that religion creates a symbolic universe that legitimizes earthly structures, thereby giving people the will to live. Thus, 
people have concepts, beliefs and value systems which engage the priorities and qualities of the social relations. Consequently, this study seeks to examine the role of religion in addressing the phenomenon of poverty. In particular the study seeks to examine the success of CoG-Kenya projects in poverty alleviation in Emuhaya District, Western Kenya. At the moment, CoG-K has gained a wide acceptance among the people of Emuhaya District of Western Kenya and also influenced their way of life.

\subsection{Objectives of the Research}

To examine the success of CoG-Kenya projects in poverty alleviation in Emuhaya District, Western Kenya

\subsection{LITERATURE REVIEW}

\subsection{Empirical Review}

Historically, the church is known to give services on voluntary basis and therefore seen as the servant of the community. Social action is part and parcel of religious work. The two, that is, material prosperity and spiritual enhancement should be intertwined in a way that fullness is felt in the lives of the suffering humanity. Consequently, the church that is called by Christ's name cannot find a comfortable home in an oppressive and dehumanizing situation. The church as a liberating community cannot attach itself to the oppressive status quo, resisting and resenting change. The purpose of the church is to establish the reign of God. As such, the CoG-K is a living sign of the Kingdom of God on earth. The works of the church serve human dignity and basic human needs. According to the Second Vatican Council, the church stands for the person in the community of persons for the common good (Tarino, 2005:153). By positioning itself outside partisan politics the church-related organizations address freely those matters found in the socio-political order, cultural sphere, and economic life by raising questions pertaining to moral value.

There is without doubt growing realization among scholars that faith dimension should be added to development work (Belshaw, 2001). Churches are involved in development work because their membership includes the poor in Africa. Belshaw's view is that if there is any special group that lives, understands and indentifies with the poor in Africa, it is the church. When the church talks of the poor, it is talking of its own. It is the church with the poor and of the poor. Thus the church should use its identity to community's advantage. It is a better mediator for development aid and an effective channel since it has a biblical basis for that kind of work. Belshaw suggests that it is crucial that the local church ministers as well as members to actively participate in alleviating poverty in the community. Belshaw however does not consider the issue of the role of the church in alleviating poverty and its implications to matters of the oppressed

The church's activities' and ministry cannot be limited to the individual's needs, conversion and preaching, it should be open to the society in history. The preaching, repentance and conversion is not a secularization of the existing conditions, but rather a strong orientation towards the future and liberation. The individual and the community must behave as penitents, walking on the road of conversion. Sin and redemption have social dimensions and, therefore, enter into the political sphere (Ibid.). It follows, that the church, as an institution, through its members, has to oppose any organization, or any economic, social or political structure, which oppresses people, and which denies them the right and power to live as children of the living God. 
Vinay (2005) observes that the church is an effective grassroots' organization in the world, which has important role to play in alleviating poverty of the continent. For that reason, the church and its relief and development agencies are called to a holistic mission of Christ to the less fortunate people, displaying his love, compassion and justice. The church projects often have a language of holism, but a practice of dualism. Many development agencies ignore or underestimate the importance of the church for sustainable relief and development. He adds that the gospel is the most significant force for social change. As a result, the expansion of the church in Africa has important implications for the progress of the continent. Consequently, the important place of spirituality in human development is being acknowledged. Secular groups involved in development are beginning to take seriously the religious communities with whom they work with. This study used the information contained in Vinay's literature to determine the impact of the activities and projects of CoG-K in alleviating poverty alleviation in Emuhaya District.

Elliston (1989) observes that the undertaking of the church is to empower the poor through ministry, not just preach liberation in the future coming kingdom of God. But the power imparted has to be the power of the powerless, the power of vulnerability, and the power of Christ. Consequently, for Elliston (1989:67):

Poverty means death. It means death due to hunger and sickness, or to repressive methods used by those who see their privilege position being endangered by any effort to liberate the oppressed. It means physical death to that to which is added cultural death, inasmuch as those in power seek to do away with everything that gives unity and strength to the dispossessed of this world. In this way those in power hope to make the dispossessed an easier prey for the machinery of oppression.

As indicated in the above citation, the church of which the CoG-K is part has a duty to proclaim the message and take care of human needs, which will then empower the poor people. The church should be at the cutting edge of formulating an alternative economic system based on the kingdom principles. Christians should not be satisfied with the current system that consumes inordinately, endangering life on earth, threatening the survival of people and their culture, alienating and mutilating the human kind, and perpetrates a world of extremely rich and extremely poor people (Ibid.).

Kemp (1975), criticizes the church in general for abdicating its responsibility for the poor. The absence of the church from the needs of the poor may be the result of complete geographical relocation. The church separates itself from the needs of the people by relocating in a community where such problems are not present. It is also possible for the church to remain in a poverty area geographically but still be "absent" in the sense that it does not demonstrate genuine concern. The church again in the minds of many is identified with the middle and upper class that has exploited or patronized the poor and minority, and it is rejected with all the rest of the so-called establishment. Thus, anyone representing the church stands disadvantaged with such people. The fact also must be recognized that the established churches to a large extent have abandoned the poverty areas and moved to the suburbs. On the positive side, many of the poor have had a valuable meaningful relationship with the church. For generations, the church had been a source of comfort and strength to the poor and the disadvantaged (Ibid.)

Bryne (1975) observes that the Christian church in Africa has more or less accepted progress as a fundamental part of the ministry and office of Christ and consequently required of by 
apostolate for the betterment and development of the community. He shows the necessary humanitarian impulse implemented in the concern with development trends to make Christians feel this is something they can identify with and should be involved in combating hunger, poverty, ignorance and disease or the adverse effects that the wrong kind of development can have on the society. Mission organization has been involved in various projects. However, Bryne's work does not show how the CoG-K has concerned itself in development of the society. This gap is what this study seeks to address.

Bujo's (2002) consideration of Jesus Christ as liberator in African situation is therefore much more than a metaphor. He attempts to present the only Jesus that can be comprehensible and credible among the African masses and the poor. In the long run, it is only Jesus who can evoke the admiration of the rich and powerful of the land. This is the Jesus who actually calls individuals and people to freedom by his word and action. He does this through God's continual self-revelation in history, the Christian God being a God of revelation. In the process, he gives voice to the voiceless; to that farmer, for example, can demand fair prices for their product. He instills courage in the weak hearted so that industrial workers, domestic servants and casual laborers can say "no" to the arbitrary exploitation to their person and labors. He provides hope to the prostitutes, parking boys, the sick and the lame so that they may realize that despite their degradation, suffering and handicaps, they are equal members of the society and children of God, with dignity in his sight. He confirms the idealism of the youth so that they may accept the challenges that the future belongs to them, that they can make a better place for everybody.

At the same time, as a necessary consequence to the liberation of the poor (because his salvation is intended for all), Jesus is the liberator of the rich, the proud, the intellectually conceited, the satiated. This also is to be understood in a real, rather than simply a metaphorical sense (Bujo, 2002). Through events in human history picks their consciences to conversion, attention and dependence on Him. Sometimes he violently wrests power from them to shame them. In the scripture, the songs of Moses and the people after crossing the sea unharmed (Exodus, 15:1-18) are examples when considering the historical Jesus. His life and ministry were dedicated to the promotion of awareness of the dignity of the human person as a child of God. Jesus identifies Himself and God with those who suffer from poverty, oppression and rejection. By that same commitment, He called the perpetrators of oppression to conversion. Thus the lamentation of Jeremiah $(8: 21-9: 1)$ is also that of Jesus:

The wound of the daughter of my people wounds me too,

all looks dark to me, terror grips me.

Is there not balm in Gileads any more?

Is there no doctor?

Then why does it make no progress?

this cure for the daughter of my people?

Who will turn my head into a fountain?

and my eyes into a spring for tears,

So that I may weep all day, all night,

for all the dead out of the daughter of my people? 
When we speak of Jesus as a liberator, then we refer to his assurance of solidarity with us in the struggle - His struggle - to diminish poverty among the masses of the people it is a struggle to prevent the untimely death of millions of children due to malnutrition, poor hygiene and lack of medical care. Christ is liberation of human person, for development and healing - idealistically, through the church

Stafford (2000) warned that the church should not lock herself by neglecting her mission, but should labour unceasingly in establishing a solid foundation for the welfare of individuals and of society. By the very nature of its mission, the church is to teach values peculiar to the liberty, by which Christ has freed the humanity. The life of the church is supposed to be a sign of freedom and commitment to true liberty and liberation. The struggle for justice and active participation in transforming the world are essentially the mission of the church for the redemption of the human race and its liberation from every state of oppression. This literature is helpful in determining the mission of the CoG-K and how it should not be departmentalized, but be intergalactic for the welfare of the whole person, both physically and spiritually.

Gumo-Kurgat, (2004) observes that the missionaries were not only interested in establishing the church among the people by opening up missionary stations, but also were interested in improving spiritual, social, political and economic living conditions of the people. In this regard, it was its mission to start development projects in an effort to change the living standards of the people. The study also sets to examine the traditional, social, economic, religious and political structure of the Luhya of Busia District before the coming of Christianity and to facilitate an analysis of the contribution of the Catholic Church to social change. This literature, therefore serves this study as the guide in finding out what prompted the missionaries in development. However, the contributions of the CoG-K in development have not been acknowledged in her study. The aim of this study is therefore to analyze the role of the COG-K in alleviating poverty in Emuhaya District of Western Kenya.

CoG-K originated in the United States in the early 1880's. Its aim was to liberate God's people from suffering and sectarianism. Later it became a missionary group organized by the Mission Board in Anderson, Indiana. Missionaries were sent to different countries of the world to evangelize and bring the "lost" people to the cross of Jesus Christ. In Kenya, they centered their activities and programs in Western and Nyanza Provinces (ESDP, 2008). Anduuru (2005:18) comments that:

Mu 1905, Augost 15, mu milimo chibili omumiseni owarumwa okhurura South Afrika yola ha Kima nasimikha lihema lilie mu musaala kwalangwa esikomoli. Namanyisibwe nende omuruchi otieno wa Ndale, ma nachaka okhukamba amangana ko mwami owalangwa Yesu. [ In 1905, August 15, on Tuesday, the Missionary from south Africa came to Kima and planted the church under a tree that was then called 'eskomoli' and began preaching about Christ]

A primary emphasis of the tenet of the Church of God missionary preaching's was personal holiness in the Christian life. More essential was the idea of "the church" as the body of Christ comprises all Christians. On the basis of this there was a strong attraction of the African towards the Gospel, thus the planting the CoG- K in Emuhaya District then in the area of North Kavirondo (Ibid.). It was a strong movement with an expression of the universal church without the restrictions of human culture and organizational structure. For Ochilo (2005:24): 
The Church of God fellowship activities tended to centre on the Gospel Trumpet publication. This printing, since changed to vital Christianity, was an organ for expressing the principles of the church. The offices became a clearing house for information and then a kind of cocoordinating agency for events and activities. Funds to support the first overseas outreach of the fellowships were channeled through these offices. The "Gospel Trumpet Home" became an institution for church workers of all types as well as those involved in publications of the magazine.

Though the above argument focuses its general attention to CoG-K God activities and how it reached the Africans, it indicates that the CoG-K did not have an official statement about poverty. However, it took its stand on "basic holiness truths that all people belonged to God and are called to universal priesthood at all times" (Ibid.). According to Anduuru (2005), when the South African Compound and Interior Mission began work at Kima, Emuhaya District in the Western Province of Kenya about 1905, and Robert Wilson first arrived at Kaimosi from his home in South Africa, he stayed there for several days before he traveled to Kima in Bunyore. The South African Compound and Interior Mission under the leadership of A.W. Baker continued to carry on his ministry at the gold mines in Johannesburg, thus sending Wilson to Kenya (Hagemann, 1991).

When Wilson first came to Bunyore he met Chief Otieno who gave him land to establish a mission station. He had an African helper from Zululand whose name was John Bila. They were very friendly to the indigenous people who in turn developed an interest in the gospel. On each and every Sunday Wilson blew his trumpet to mark the Lord's Day (Ibid.). When people came, he enticed them by throwing some groundnuts and coins. He also would provide them with salt. Gradually, a handful of Africans were attracted to these strangers who lived in their midst. The people became so acquainted with the missionaries that they nicknamed Wilson "Kabole," a Lunyore word meaning "speak" (Makokha, 1996). He was nicknamed Kabole because of his ability to speak boldly about the poverty and needs of the people. Therefore, after spending much time and effort at preaching and teaching, some native people showed interest and desired to be followers of Christ as well as helping others to understand the Gospel truth of Christ. As a result of his witness, he baptized the first two converts in 1910 (Ibid.). These were Yohana Owenga and Matayo Sikalo. In the following year Jairo Opetsi and Yusuf Okwemba accepted Christ as their Lord and were consequently baptized in river Yala. These four people became the first CoG-K preachers of the Gospel amongst the people of Emuhaya District.

CoG-K converts were taught and also expected by the missionaries to live together in Christian communities. Thus, after the first baptism of the four, a Christian community was formed at Kima. The purpose of these communities was to keep the converts from mixing with the heathen and their practices, for the fear that they would be forced to participate in these practices. These communities proved to be very popular, for the residents were well cared for and were taught how to read the Bible and also how to write (Ibid.). The fact that the practices of these Christians were so different attracted many people to join them. As time went by, Kima became so populated with Christians that other villages had to be established to accommodate everyone who wanted to join. The people regarded the four men who were the first to be baptized as their leaders as well as preachers of the Gospel. It is this information contained in Makokha's literature that this study uses to determine the impact of the CoG-K's teachings to people's participation in alleviating poverty in Emuhaya District. 
As a result of the marked growth of the CoG-K, she contextually developed in terms of theology and congregational structural pattern of leadership (Ibid.). The year 1995 formed the watershed of the history of the CoG-K. A rhythm of social activities of the church changed in such a way that she became a "robed" church. This initiative was made the by the church to embrace the changing time of it populace. The CoG-K under the leadership of Rt. Rev Byrum Makokha and assisted by a group of four: George Abura, Ainea Mukabana, Nelson Obwoge and Fanual Siberenje (Makokha, 2005). The church embraced the use of clergy uniforms for its ministry all over country. The bishop was robbed red while the other clergy who had been able to achieve high education of either bachelors' degrees or Masters Degrees were robbed purple. Makokha's literature has articulated some activities in the $\mathrm{CoG}-\mathrm{K}$ which this study as a guide in analysis people's contributions in poverty alleviation.

Following this historical event, the head of the church who had originally referred to as the executive secretary was officially conferred the title bishop in 2003 following the general assemblies' recommendation. This evident move affected the activities of the CoG-K in Emuhaya District and in Kenya in general, both economically and spiritually. Thus, the Church of God in Kenya, especially its missionary arm, has normally understood social work of society to be essentially part of its task. While the focal point of its mission has been to communicate the good news of Christ, to call men and women to repentance and faith, and to baptize them into the church, it has also involved a process of teaching them to observe all things that Jesus commanded.

\subsection{RESEARCH METHODOLOGY}

This study is a cross-sectional research that sought to give an examining and descriptive scrutiny of the CoG-K's activities in Emuhaya District. This study was carried out in Emuhaya District of Vihiga County.The district borders Vihiga District to the West, Kakamega South District to the north, Siaya District to the east, and Kisumu West District to the south. This study targeted Emuhaya District which has a population of 180,000 people who are members of the CoG-K (CoG-K Assembly, 2007). These were represented in all the 141 CoG-K congregations in Emuhaya District. Other participants who were thought to have important information for the research were the CoG-K leaders, directors and the church elders who were purposively sampled as discussed under sampling procedures. Within the CoG-K's population, a sample size of 312 respondents was sampled for oral interviews, administering the questionnaire and focus group discussions. Saturated sampling technique was used to opt for the 4 administrative heads of the CoG-K namely the Bishop, the General Secretary, CoG-K Treasurer, CoG-K trustee and the 16 heads of departments for in-depth interviews. To obtain data for analysis, qualitative methods of data collection, which include in-depth oral interviews, focus group discussion, observation and documentary analysis, were employed.Data collected through the questionnaires, personal interviews, focus group discussions and observation was synthesized systematically and logically compiled to determine the role of CoG-K in alleviating poverty in Emuhaya District. Data was coded manually and organized under different themes. Data was then synthesized systematically and logically compiled and presented descriptively through use of narratives and frequency tables. Conclusions were made according to the findings of the study in light of the research questions, objectives and theoretical framework. 
European Journal of Philosophy, Culture and Religious Studies

ISSN 2520-4696 (Online)

Vol.1, Issue 2 No.1, pp1-24, 2017

www.ajpojournals.org

\subsection{RESULTS AND DISCUSSIONS}

\subsection{Education and Training Facilities}

The people of Emuhaya District were among the first to be exposed to education during the missionary activities in Kenya when the first mission station was established at Kima in 1905 (ESDP, 2008). Since then, quality education has been perceived as playing a significant role in human development by empowering people to improve their livelihood. According to Gumo-Kurgat (2004: 226), education has a potential role in promoting development goals. Education is an essential component of the social service within the broad framework of social development (Ibid.) The availability of physical facilities in primary, secondary schools and colleges in Emuhaya District constitute key indicators of quality education to the community.

The CoG-K founded a total of 48 primary schools, 20 secondary schools, and 1 college in Emuhaya District, through the guidance of the Holy Spirit. According to the CoG-K records as indicated in Table 5.1, the CoG-K schools serve the following number of students in Emuhaya District:

Table 1: Student Population in Cog-K Primary and Secondary Schools in Emuhaya District

\begin{tabular}{|l|l|l|l|}
\hline & Males & Females & Total \\
\hline Primary Schools & 26,027 & 27,212 & 53,239 \\
\hline Secondary Schools & 4,740 & 5,004 & 9,744 \\
\hline Total & 30,769 & 32,216 & 62,983 \\
\hline
\end{tabular}

Source: CoG-K General Assembly, 2007

The foregoing table shows the achievements of the CoG-K in Emuhaya District in establishment of education institutions which were as a result of the CoG-K education act of 1904 (CoG-K Archives, 1904; CoG-K GA Minutes, 2006) which recommended that the church establish learning institutions which will impart knowledge to the "primitive" Africans. Thus since 1908 the $\mathrm{CoG}-\mathrm{K}$ has been involved in education system, thus:

Church of God in Kenya started and established their schools, trained and employed their teachers, paid salaries of their teachers, promoted their teachers, supervised their schools, inspected their teachers and disciplined those who deserved such discipline. The church of God assumed the role of manager. As time went on in 1963, Kenya became an independent country and new rules and regulations on education were inevitable. Soon after confirmed the importance of voluntary agencies "churches" but it quickly became evident that would be a shift in the church and state relation as the Ominde report and later government move in running of primary, secondary schools and some colleges. Following the Ominde report that education was a social and therefore the responsibility of the government, the ministry of education issued an order in 1965 requiring the churches to hand over their schools voluntarily to the government. The church continued to make decision on the religious education curriculum and also had the right to schools to inspect the teaching of religion. The Cog-K therefore remained a sponsor of many of its schools (CoG-K archives, Educ. Vol 1, 1968)

Under the chairmanship of Ominde, the Kenya Education Commission Report of 1964 was implemented. The report underlined the accountability of the Government; thus, it recognized 
the inclusion of religious education in the school curriculum. The CoG-K sponsors most of the primary and secondary schools in Emuhaya District (Lipakhala: OI, 16/02/2008). Data from Table 5.1 indicates that in Emuhaya District, more girls are enrolled in both primary and secondary schools. Thus, these figures indicate that in future, there will be more educated women than men. However, the worrying issue is the quality education in the schools. Poor quality is generally reflected in terms of performance, adequate and inappropriate classroom, and luck of desks for the pupils, lack of textbooks and trained teachers.

While some CoG-K sponsored schools like Bunyore Girls, Emusire Boys, and Kilingili secondary schools have marked performance amongst schools in Emuhaya District, other secondary schools like Emanyiya, Ekambuli, Esibila, Esirabe, and Mumboha there is; deficiency in sanitary facilities, science laboratories, library and teachers. These problems have partly contributed to the failure of education standards in Emuhaya district. According to Ommasaba (OI, 28/06/2008):

Our schools in Emuhaya were basically begun by the CoG-K Missionary work. Despite the achievements, the general trend in education has been declining with some schools registering as low as 200 students in secondary schools compared to 1000 previously in the example of Emusire High school. Some are performing poorly in the national exams due to lack of facilities for the students. For instance, here at Emanyinya secondary school, we don't even have a science laboratory then how do we compete with schools like Bunyore Girls. It seems the facilities have a relationship with performance in our schools.

The schools are governed by the CoG-K members who sit on the governing board. These schools are still situated within the compounds of the CoG-K churches, and people in Emuhaya still refer to them as CoG-K sponsored. The historical, geographical and cultural connection between schools and the church is important in order to understand the continuing moralizing and civilizing aspect of education. Religion and education are closely knit together in the project of converting students into Christian 'readers' of a modern state. One aspect of this project is to continue having CoG-K chaplains whose purpose is to enlighten student's minds and reading of the Bible.

Historically, some people in Emuhaya said they had experienced that education could be the 'key to success'. This is still the motto of Emusire High school. Individuals who had been to school and had a formal education were able to get jobs as civil servants, found prosperity and came back to 'develop home'. A handful of families in Emuhaya served as prototypes in the entire community for the success of education. They took up the position of a local elite who had invested in children's' education and returns in the form of wealth. Most families tried to educate their children, but due to the relatively high school fees many children dropped out before they finished secondary schooling (Ibid.). Thus, the CoG-K through its congregations has helped by organizing for "harambee" to raise funds for the poor families to take their children to schools and colleges. However, according to Otaha (OI, 15/02/2008):

In fact the so called free primary and secondary schooling in Kenya has not helped the poor people. The government duped people that our children will be able to obtain knowledge. It is so expensive and so students still drop out of this learning institution.

Children especially boys - who stopped schooling after primary level were in families regarded as "failures" because education system was geared toward advancing to next academic level and ultimately getting salaried jobs. 
By 1967, the CoG-K had abdicated the responsibility of solving the above problem to the Kenya government (CoG-K archives, Educ, vol 3, 1968). As a result, there was a reversal of educational attainment and high level of school dropouts, partly because the of government's inability to address the spiritual needs of the students. This implies that the spiritual needs of the students can be reflected especially in the school dropout. For Instance, it was reported that girls drop out of school due to early pregnancies and end up as single mothers or unplanned marriages partly because they were not taught biblical truths. Therefore, the literacy of the girl child has been affected in overall.

Significant differences in levels of education among the respondents were noted. According to Asiachi (OI, 12/11/2008) over 60 percent of the women respondents had no schooling at all and were, thus totally illiterate. However, some of them had managed to develop some reading skills through repetitive bible reading. A few of them could read and write. This seems to indicate that poverty was prevalent among those less educated. Most of the respondents were married. This shows the social importance the society places on marriage and children, but who however, do not own property. The divorced, widowed and married people represent $6 \%, 16 \%$ and $82 \%$ of the sample respectively. The CoG-K in conjunction with sister congregations in Uganda, Tanzania, USA and Canada began the Kima International School of Theology (KIST) to offer higher education in East Africa. The school aims at sponsoring university level education for its students so as they can be able to serve the people at the local level. This is one way by which the college is involved in social welfare especially with the poor students (Ibid.).

According to Smith, the principal of Kima International School of Theology, the number of women students registered for degree courses in the college has fluctuated between $8 \%$ to $24 \%$ of the total intake (Smith, OI, 14/12/2008). A special concession has been given to female student pastors since the inception of KIST in 1995, by allowing them to enter the college straight from the secondary schools, instead of first serving two years in some place of employment as is the case of the male student. Even so, a great proportion of the women student pastors, whether married or unmarried, give birth to children before they finish their higher studies (Ibid.). This is a strain on their studies, and in most cases, it means that they can complete their degree after along while or even not complete these studies. The educational policy at KIST was devised to provide equal chances for all CoG-K adherents from all levels and sectors of the society (Kiboi: OI, 11/08/2008). How fully this can happen is dependent not only on the educational policies, but also on the structure of the society and the manner of the implementation at every level.

\subsection{Health Care and Nutrition Facilities}

The importance of good health for development cannot be over emphasised. The accessibility of health facilities is critical to the development of any society. In addition, health is one of the most essential things for a person's well-being. It is also one of the indicators of social welfare. Efforts to improve health and hygiene through CoG-K institutions have a history in Kenya. The earliest intervention was made by the missionary board of the CoG-K in the 1900's (Cavanaugh, 2008). As part of the CoG-K's strategy to spread christianity and civilization by propounding the gospel of need orientation, missionary schools and catechist reading were established in Kenya. According to Kiboi (OI, 11/08/2008):

From the beginnings of the CoG-K, the ministry of healing has been integral to the faith perspective. Certainly Jesus demonstrated that holistic healing was intrinsic to the gospel he 
proclaimed in mark 1:25-30. Thus he is referred to as the healer and great physician, and issues of healing are vital to the abundant life he came to bring. Following his death and resurrection, Jesus' healing continued to be manifested through the church of which the CoG-K is part. Accordingly, people cure but God heals

The citation above captures the widespread CoG-K's adherent's thoughts concerning the interrelationship between religion and health. The aim of the CoG-K missionary schooling was threefold: "to teach Kenyans the Christian religion and its practices, to teach the Kenyans secular knowledge and skills and finally, to look after the health of Kenyans and thus uplift their health conditions. The missionaries regarded health and hygiene as a necessary foundation for learning to read the bible and God's word based on the philosophy of - a healthy mind in a healthy body. This general attitude to health as a necessary vehicle for learning apparently continues up to date (Ambira: OI, 16/02/2008).

The responsibility for health issues is perceived to be integrated in a hierarchy of care in the family of the CoG-K members. Therefore the church feels the need to partner with the government to safeguard this. Although, at the time of independence in 1963, the government of Kenya identified disease, illiteracy, ignorance and poverty as the main problems to be addressed in the post-independence era in order to achieve sustainable developments (Ondeso: OI, 29/06/2008). A policy on poverty was stated in the session paper No 1 of 1965 on the Church of God health institutions and its application to planning in Kenya. The CoG-K noted that:

By availing health services to the citizenry, the $C o G-K$ and its faith based organizations will go along way to fighting poverty. It is assumed that a healthy person is better placed to undertake activities, which will improve his/her economic conditions. Those who are ill and are afflicted are unable to help themselves (Ibid:45).

The provision for basic health care in the CoG-K stem from the argument that a "healthy person is always a strong person for oneself and for the community" (Anjere: OI, 12/02/2008). One needs physical strength in order to work and earn a living, thus fighting causes and effects of poverty.

The CoG-K began hospitals with the goal to partner with the government in eradicating the problem of disease (Wekesa: OI, 23.12/2008). The range of medical facilities in Emuhaya District includes public and private hospitals, public health centres and dispensaries and private clinics. The CoG-K began 2 hospitals: one at Kima and the other at Emusire. But because of clannism and corruption, the Emusire hospital collapsed. As a result, many people are dying at home from treatable diseases (Ibid.). It is evident that the significance of good health cannot be overemphasized in development. However, CoG-K in her push for need oriented evangelism is planning to reconstruct the Emusire Clinic and begin health services (Ibid.). Evidently, the availability of health facilities is crucial to the delivery of the community from suffering. It should be pointed out that the availability of health facility points out how people access medical services. According to Ndale (OI, 0101/2009):

It you have healthy people in the community; they will participate in building their own life's by working towards economic gains. The community shall not have beggars which is usually a consequence of poverty. This means that the people in Emuhaya District will be self-reliant and productive both socially and economically.

A number of problems impede the provision of services in the medical institution at Kima Mission Hospital. First, are inadequate trained personnel, particularly medical doctors and 
sufficient facilities to serve the growing population in Emuhaya District (Wekesa: OI, 23/12/2008). Kima Mission Hospital has a clinical officer who is in charge of running the hospital. This means that in the absence of medical doctors, patients have to be transported to Kisumu for specialized treatment, yet the hospital does not have an ambulance. Therefore hired means must be sought and this is not readily available. The poor distribution of hospitals and equally poor medical services in these institutions has partially contributed to mushrooming private clinics in Emuhaya District. But these clinics do not offer better services given that personnel who are not properly trained operate most of them. Unlike the mission run hospital, these clinics are less expensive by local standards and stock some medicine for its patients to use (Anjela: OI, 29/02/2008).

Home treatment with pharmaceuticals purchased through the local shops was however, by far the most common way of dealing with 'everyday' illness in the family. The importance of the private and informal sector for health care has been described in a number of studies in Kenya (Whyte, 1991). Health problems among the CoG-K adherents in Emuhaya District are not caused by lack of knowledge and information, but rather lack of resources and power to implement knowledge (Ochami: OI, 18/12/2008). This seemed to be the central point which was known by the CoG-K planners and implementers of health education in the church but which was not directly addressed. This is a dominant feature in many health projects that the CoG-K has began, even though it is well known that lack of knowledge is not the root of the problem. CoG-K pastors in Emuhaya District saw themselves as providers of knowledge, but felt understandably unable to tackle questions and problems of resources, and therefore manage to avoid their own feeling of helplessness by simply not confronting the fact that they are not able to implement what they taught. Furthermore, it was regarded as politically sensitive to blame the shortcoming on the government or external factors. This meant that they continued teach in a somewhat inefficient manner. The ill-heath records study at Kima Mission Hospital is illustrated in figure 1. 
European Journal of Philosophy, Culture and Religious Studies

ISSN 2520-4696 (Online)

Vol.1, Issue 2 No.1, pp1-24, 2017

WwW.ajpojournals.org

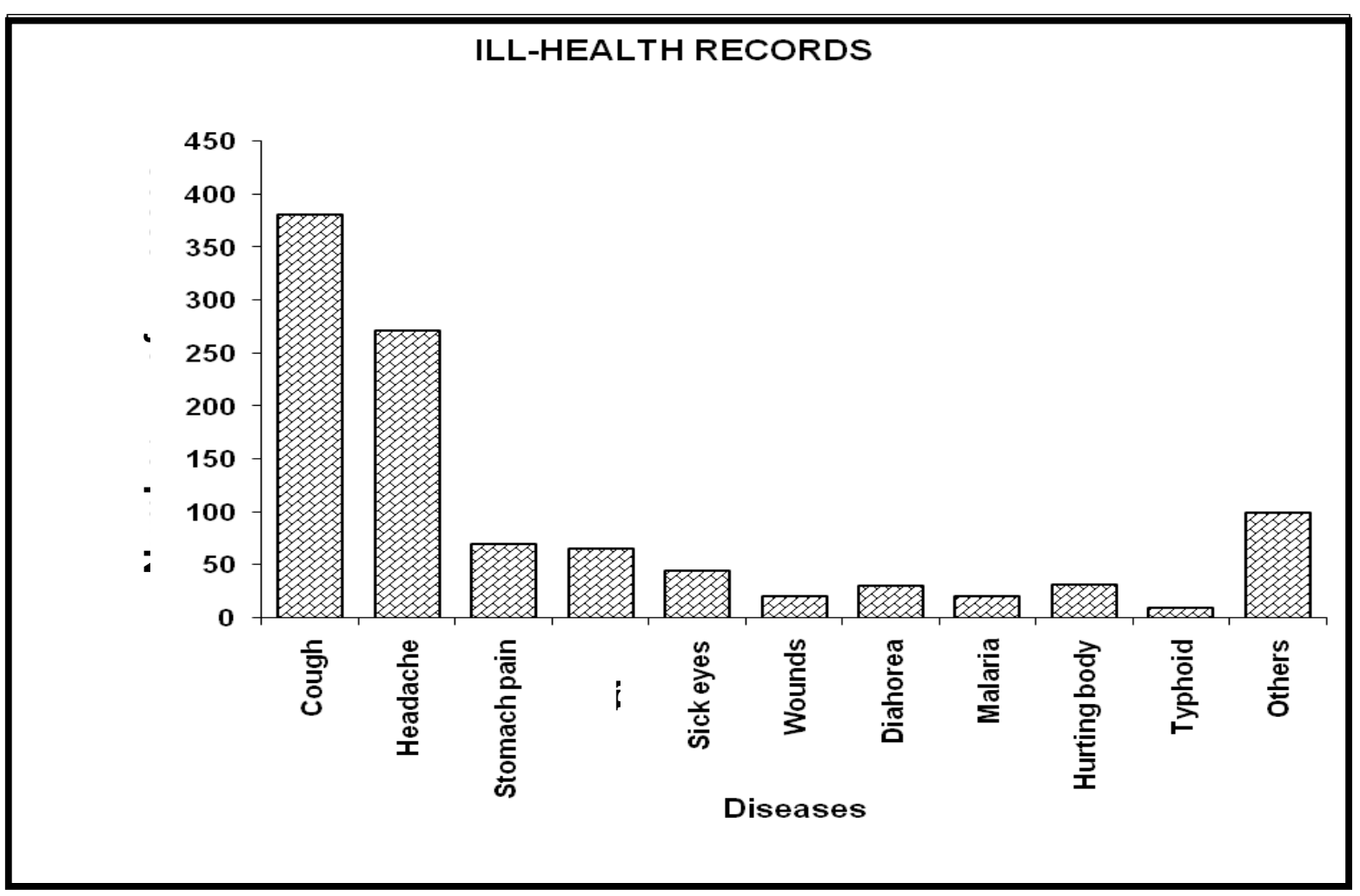

Figure 1: Ill-Health Records

Source: Kima Mission Hospital Records

As illustrated in figure 1,the study found out that the 10 most common symptoms and illness that were reported were (in decreasing order) cough, headache, stomach-ache, flue, sick eyes, wounds, diarrhoea, malaria, hurting body parts, and typhoid. HIV/AIDS was noticeably absent from these records. Many of the common disease records in the clinic corresponded with the symptoms reported. Additionally, wounds and hurting body parts (mostly from accidents) were common among the elderly. Most of the families in CoG-K had experienced one of their family member's deaths especially through miscarriages. On average, women in CoG-K gave birth to seven children during their lives (Omenda: OI, 12/02/2008).

This fertility rate combined with the average of one miscarriage meant that practically many families experienced one or more of their children dying. According to Amakhanga (OI, 17/02/2008), "we do not count children before they are big enough to be counted upon". The health situation for the general population was indicated by the low life expectancy of 45 years on average, which had dropped dramatically during the last decade due to HIV/AIDS (Ibid.). There were frequent burials in Emuhaya District, and many of these deaths were caused by HIV/AIDS. Thus, HIV/AIDS threw a dark shadow on people's lives, but so did other common diseases like malaria. The tendency to focus on HIV/AIDS - locally, nationally and internationally - may be due to AIDS' short history, its fatal destiny and connection to sex, taboo and morality (Wekesa: OI, 23/12/2008). In the church's' records at Kima Mission Station, however, it is still the 'old' diseases such as malaria, measles, pneumonia and diarrhoea that account for most deaths and diseases among the populace (CoG-K Annals: Vol 2, 2007). 
At funerals that were conducted by the church, the reason for the death that was mentioned is that the "Lord loved the deceased more than we did and thus God has decided that he/she rest" (Ochola: OI, 21/12/2008). Thus, HIV/AIDS is not mentioned as the main killer. Residents of Emuhaya District desist from mentioning HIV/AIDS because of the resentment. Although the means by which AIDS is transmitted is widely understood amongst the people, they often suggest that the disease may have been deliberately exported to Africa by the Western countries with the intention on depopulating the continent.

Apart from health problems according to Litunya (OI, 28/12/2008), the major factor responsible for the high poverty levels among the CoG-K adherents in Emuhaya District was insecurity. Security in the area is poor. The climate of uncertainty meant they could not participate in economic activities. Thus, while Emuhaya District could register some economic improvement, it has been in a climate of high insecurity (Ibid.). Armed attacks could be expected at any time, resulting in feelings of insecurity and hopelessness, which impeded any thoughts of plans for the future. This meant that businessmen could sell their commodities under difficult circumstances. Violence against the property and person in the form of crime, vigilantism, and communal conflicts is interlinked with poverty and underdevelopment. For example Stewart and Fitzgerald (2001) find that conflict is a major source of poverty, where low income leads to conditions which are conducive to violence.

It was established that violence and associated insecurities tend to disrupt normal economic and social activities, undermine democracies and public discussions and frustrate the development of a well-functioning market economy. Not only can subsequent economic crises plunge large percentage of the population into poverty, it can lead to political unrest and turmoil that create long term effects on the economy and on public safety. According to Makokha (OI, 30/11/2008):

The post-election violence of 2007 was not caused by the disputed counting of ballot papers but the long grievances associated with low income high levels of poverty and unemployment; environmental pressures leading to conflict over resources, especially land; and the failure of the social contract to deliver public service, security and income.

Failure to maintain either social integration in, or build hope for poverty reduction leads to violence against property and persons. This in turn has impacts on economic activities and the welfare of the poor.

\subsection{CoG-K Agencies}

The CoG-K organisations have arisen because of the need oriented evangelism which has thus resulted in the church's involvement in social work in order to address the needs of the people (Otaha: OI, 15/02/08). Therefore, the CoG-K embodies the love of God as including serving the suffering in the community. Thus, CoG-K began social welfare institutions in order to serve the adherents in Emuhaya District. The CoG-K advocates,

...the dignity and social nature of the human person, the tights of the family, the need for intermediate associations, and a limited state with the positive function of seeking the common good...just as it is grave wrong to take from individuals what they can accomplish by their own initiative and industry and dive it to the community, so also it is injustice and at the same time a grave evil and disturbance of right order to assign a grater and higher association what lesser and subordinate organisations can do (CoG-K, 1968:46). 
This principle ensures that there is a sharing of social responsibility at all levels. Since the CoG-K organizations are informed by Christian vision under the inspiration of Christian faith, their commitment become specific by approaching social question with a difference arising from Christian values. The CoG-K teach that direct involvement in the effort of transforming social structure must be understood as a process of establishing the kingdom of God which is to transform all dimensions of human life.

The CoG-K leadership in conjunction with the Kima Integrated Community Initiative Program (KICIP), the Child Development Programs and Kima Community Health and Nutrition Centre, have initiated programmes aimed at improving the quality of life, especially those affected by poverty and infected HIV. KICIP's objective is to help in giving information and support in terms of grants and physical help like building houses for the affected while the Compassion aims at helping the orphans to attain education in the community so that the future of those supported may be better (Omusore: OI, 29/02/2008).

KICIP started as a primary health care program under the CoG-K at the Kima Mission Hospital in 1987. It started as an entity which sought to understand the needs of the community within the CoG-K fraternity. By then, its main activities were health education, expanded programme on immunization, maternal child health, family planning and nutrition. By 1994, the CoG-K and KICIP based programme was reported to have been superseded by the target people it served. Thus, there is a need for expansion in its activities especially in sustainable agriculture, water and sanitation and HIV/AIDS awareness. According to Wafula (OI, 01/01/2009), the idea of a community implies that members come up with their needs as well as their abilities which will then be empowered by the KICIP to go about their problem.

The KICIP moved from Kima Mission Hospital to the CoG-K mission station at Kima under the leadership of Elimina Omusore. According to Elimina (OI, 29/02/2008), the KICIP was registered in 2005 under the NGO board as a non-governmental organization. The organization has a board of governors of 11 members with various experiences concerning the management of rural projects. It has continued to draw funds from the church, Poverty Eradication Commission and the Tudoe Trust, which enable it to run itself effectively.

It was established that the KICIP has had an impact on the people's way of life, thus apart from teaching the farmers about organic and mixed farming, the organisation has built 10 iron roof homes: 3 at Emusire, 2 at Esirulo, 3 at Essunza 2 at Ibona specifically for the poor families; provided fees for 600 orphans in Luanda Division; provided goats to 40 families in Emuhaya district; KICIP helped in building water springs that had not been protected as identified by the community and also supported school to build water tanks. Institutions that benefited from these activities are Emanyinya, Ebukhaya, Esirabe, Ebusirasti Ebusubi, and Esikhuyu secondary schools (KICIP Records: Vol.9, 2008).

Previously, the Child Development programs were began in the CoG-K in 1987 (Omusundi: OI, 18/08/2008). Mary Kageho (OI, 11/11/2008), the coordinator of Esirabe $\mathrm{CDC}$, noted that the goal of the centre is to help the needy child develop socially, physically, emotionally and spiritually. The social worker at each centre is employed by the CDC with Child Development centre baseline survey in the community to recruit the needy children to the centre. Recruitment is also done through schools that are sponsored by the CoG-K and the congregation of the church. The economic status of the parents or the guardians and the family size are some of the factors that are considered before the child is recruited. The age limit for the sponsored child is 4 to 21 years. But the program continues to sponsor the child 
who qualifies for university learning. At Kima CDC 3 students; one at Moi University and 2 at Kenyatta University are sponsored for higher education.

The Director of the CDCs in the CoG-K sits as the chairman in all the advisory board of the entire 6 centres in Emuhaya District. He facilitates seminars meant to educate the members of the $\mathrm{CoG}-\mathrm{K}$ on the importance $\mathrm{CDC}$ 's and its recruitment, thus contributing to informal education of the public. However, According to Oyaro (OI, 14/01/2009):

The selection criteria include: total orphans; children from single parents; those whose relatives are poor; abandoned children, children with chronic ill parents and the children who are unable to get basic needs of life.

Thus the programs provide the following: scholarship to at least 300 children in each of the 6 centre (Mutoka: OI, 22/08/2008); vocation training in disciplines like mechanics, tailoring and information technology (Kageho: OI, 11/11/2008). A visit to one of the CDCs at Esirabe, it was established that apart from the organization paying for the children fees it also purchased materials such as school uniform and taking care of the medical subsidies. The Esirabe CDC also provided food for the children both at school and at home. In their home, the program provided an animal such as a goat or a cow to be tended by the child's family. A deficiency was however noted about these centres: the sponsored children totally depended on the programs for help.

According to Wekesa (OI, 23/12/2008), the Director of the Kima Comprehensive Care Centre, sensitization and guidance to family life education and the use of family planning method continue to be main endeavours of the organization. The KCC serves mainly the poor widows and the orphans whose parents died from HIV/AIDS by providing medicine commonly referred to as ARV's for the people as well as food, shelter and prayers or spiritual nourishment. Wekesa, reported that the organisations helps 1658 poor CoG-K adherents in Emuhaya District and could not disclose more information for discretion purpose (Ibid.).

The Cell Life Church Program (CLCP) of the CoG-K through the guidance of the Holy Spirit encourage those infected and affected by the HIV/AIDS pandemic to attend the counselling sessions at the centres. However, efforts of the CoG-K in providing guidance and counselling services to the community, is faced with different challenges. According to Zibrosa (OI, $25 / 11 / 2008$ ), a nurse at the centre, most of the women, unlike their male counterparts do not fear to go for voluntary counselling and testing. She reported that the church must continue to encourage adherents to attend family planning session because this is the only way to get to plan for the future. Thus, the CoG-K must be an HIV competent church (Ibid.). By this she meant that the church and its organisations must understand that HIV is within its ranks and therefore respond appropriately by reconsidering its core values and mandate. Imbayi (OI, 08/08/2008) perceives that this kind of activities has contributed to dependency among the CoG-K adherents of Emuhaya District. For instance:

People do not want to work hard so as to achieve improvement in their life. There is a common tendency for the benefactors of the KICIP, KIHNC and compassion to just lazy around because they are sure of receiving help from this Faith Based Organization. This syndrome is also seen even in the management of these bodies where the Chairman, Secretary and the Treasurer still expect help substantially. The governors do not contribute any finances or ideas toward innovative ways of development of the people's livelihood but continue to muzzle fund meant to help the poor populace in Emuhaya District. This is corruption! (Ibid). 
CDC Programme, the Kima Community Health Centre and KICIP projects have been successful in imparting knowledge on leadership development through their programs, thus participating in alleviating poverty; however, they have also been handicapped because they have not involved the poor people in formulating policy that affect them (Ibid.).

It is important to note that the poor are the true experts in poverty (Omung'ala: OI, 08/08/2008). Therefore, they would give important methods on how to curb this problem that affect majority of the people in Emuhaya District. Moreover, projects designed to help the poor have had a limited impact because they are poorly planned and not well coordinated at the sector level. Also, they do not have a strategic policy for development and attention that is needed (Ibid.).

Muhonje (OI, 19/06/2008) sees a problem in the role of KICIP and the CDC's,

The KICIP and CDC's have not helped in development internally for one reason; financial aid has not been forthcoming in amounts sufficient to achieve development. If the donors pull out from the projects, the programs would definitely collapse.

The above argument shows that aid could in fact, retard growth by serving it as substitute for, rather than a complement to, domestic savings and investment. The aid has brought about a substantial amount of anti-development in the sense that it retards growth through the reduced savings and worsens income inequalities through the misuse and misallocation of aid. According to Munayi (OI, 11, 19/2008), aid has also created gaps between the urbanrural and modern-traditional sectors. Aid is not a sufficient condition of development, and it is indeed unlikely to promote it substantially. If the Emuhaya people have failed to develop without aid, its provision alone is unlikely to lead to development (Ibid.). Thus, it is important therefore to note that the majority of the COG-K may continues to struggle with poverty.

\subsection{DISCUSSION CONCLUSIONS AND RECOMMENDATIONS}

\subsection{Discussion}

Throughout the history of the CoG-K, there is a widespread supposition that people need to feel secure including those who are sick both physically and mentally. Healing in the CoG-K is generally viewed as a holistic activity, requiring attention to spiritual as well as physical aspects of a person. For this reason, the CoG-K plays an important role in education and health care in general, thus strengthening the need to integrate spiritual ideas to education and health care policies.

The CoG-K health program grew with the people needs. Thus, hospitals and clinics that are run by the church began. These include Kima Mission Hospital, and Emusire Clinic. The hospitals and clinics run by the church constitute a field in which the role to the CoG-K has contributed to development. However, the analysis of people's ideas about health may reveal a great deal about popular perception about the Western world. Although the means by which HIV is transmitted are widely understood in Emuhaya District, people often suggest that the disease may have been deliberately exported to Africa by the Western countries with the intention of depopulating the continent. With such misguided ideas, they do reveal a great deal about how Africans perceive their relationship with the West. Policy makers can learn from this. 
The CoG-K has also in conjunction with the Child development Programme started with short-term vision on the part of the CoG-K in terms of implementation of the services to their adherents. This programme was begun as tool within the church to alleviate poverty within its populace while getting assistance from donors from the well-off families in the West as is the case of the Kima and Esirabe child development Centres. Consequently, it is dependent on external assistance to finance the activities of the program. There is a culture of dependency that is encouraged even with organization that have successfully implemented their projects without external support to go out of their way to look for donations with the standard claim that they do not have "sufficient resources" to develop the project.

The study found out that the church has established four main leadership positions in its programs: these are the chairperson, secretary, treasurer and the chaplain. The members of the committee are selected by the sitting members of their leadership. The four main positions in these programs are elected by the executive committee which is answerable to the supreme seat of power in the CoG-K - the bishop. Whereas the ability of the individual to link to the program in soliciting funds is important, the leadership is required to have a good relationship with God. God is seen as the source of life and the provider of earthly resources and belongings. Since the chairpersons are leaders of the programs, it implies that patronage significantly determine the choice of leaders to these programs.

The evidence in this study indicates that participation in these programs is generally more functional than reflective. Consequently, most members tend to passively participate in making of decisions that do not directly involve the contributions of resources and sharing of benefits that accrue from the activities of the programs. Individuals may become active participants when making decisions on "who should get what" and leave the decisions to the leaders. To a large extent, most members attend meetings mainly to receive report on viability of the programs, status of the member's contributions and general management.

It is also shown in this thesis that the development programs in the CoG-K have been significant in the mediating people's access to resources or assets for improving their livelihood. The spiritual, physical, human, financial and social forms of assets have been essential in improving people's livelihood. However, this study's evidence is that these assets

have not been sufficient in solving most of the household's socio-economic problems. Some members who actually access some resources through their programs reported that the activities of the programs have not helped them solve their problems with poor shelter, unemployment, lack of school fees and medical expenses. This means that the contribution of the CoG-K programs and by implication the improvement of rural livelihood may be at most modest.

In any case, the study showed that most assets accessed through the CoG-K programs have mainly been used to satisfy immediate consumption needs of the household. The basic concern is that most of the assets do not stand a chance of being replicated or increased since they are consumed. The fact that most of these assets are obtained from outside and through patronage linkage further complicates the perspective of improving the livelihood as may result from the availability of such assets.

\subsection{Conclusions}

The study proved that the CoG-K has a role to play through her programs like Sisi kwa Sisi, Child Development Centres, Health care Units and education, thus these institutions make a significant contribution to sustainable development in Emuhaya District and are useful 
instruments for spearheading alleviation of poverty in the said district. The CoG-K's development is founded upon a spirituality of mutual sustenance and transformation through its concern for the adherents' struggle with poverty. This study found out that faith activities and the related projects implicitly advance the poverty alleviation cause, thus all development revolves around spirituality. From this perspective the CoG-K has the responsibility to engage in all aspects of development within spirituality as the foundation of such engagement.

\subsection{Recommendations}

The study submits to the fact that power lies in the CoG-K projects which, subsequently play a positive role in alleviating poverty in Emuhaya District. As a result, these study findings suggest that development will in future need to be considered in term of religious teachings. The study recommends that development experts, theologians, policy makers and practitioners should cultivate long-term relationship with the church in general and the CoG$\mathrm{K}$ in particular so as implement policy for development consequently alleviating poverty.

\section{REFERENCES}

Anduuru, I. A. (2005), Aka Abanyore: History Yo Okhwechiaka khwa Abanyole Nenda

Angogo, R. (2000), A Description of the Luyia. Unpublished Ph.D Thesis: University of

Belshaw, D. (2001), Faith in Development: Partnership Between the World Bank and Churches of Africa. Oxford: Regnum Books International.

Bryant, D and Flinn, F. (1989), Interreligious Dialogue, Voices Form a New frontier. New York: Oxford University Press.

Bryne, T. (1970), The Church and Development Dilemma. Eldoret: Gaba Publishers.

Bujo, B. (2002), African Theology. Nairobi: Pauline Publishers.

Burkey, S. (1993), People First: A Guide to Self-Reliant, Participatory Rural Development. New York: Zed Books Ltd.

Cavanaugh, W. T. (2008), Being Consumed. Cambridge: Eerdman Publishers.Consultants and Publishers. Edinburgh House Press

Church of God - Kenya. (2007), General Assembly. Unpublished GA Minutes Vol 3: Kima.

Galgalo, J. D. (2005), African Christian and the Contemporary Market Place: Materialism and the Theology of Moderation. Butere: Chadwick.Geneva: WCC.

Gumo-Kurgat, S. (2004), The Catholic Church and Social Change in Busia District, Kenya 1924 - 1995. Published Ph.D Thesis, Saarbrucken: Lambert Academic Publishing

Hegemann, L. (1991), Just Business: Christian Ethics for the Market Place. Downers Grove: Inter-Varsity Press. 
European Journal of Philosophy, Culture and Religious Studies ISSN 2520-4696 (Online)

Vol.1, Issue 2 No.1, pp1-24, 2017

www.ajpojournals.org

Kemp, C. F. (1975), Pastoral Care with the Poor. Indiana: Abingdon Press.

Magesa, L. (1997), African Religion: The Moral Traditions of the Abundant Life. Nairobi: Pauline Publications.

Makokha, B. A. (2005), Church of God in East Africa in the Next 100 year. Unpublished Paper: Kima Mission.

Mbiti, J. S. (1996), African Religion and Philosophy. Nairobi: Heinemann Publishers.

MDG Center. (2009), Taking Action to End Extreme Poverty. Nairobi: Acton Publishers.

Myers, P. (2000), "Pentecost as New Economy" in Duchrow (ed) Colloquium 2000: Faith Community and Social Movement Facing Globalization.

Nyaundi, N. (2003), Introduction to the Study of Religion. Eldoret: Zapf Chancery Research

O'Brien, J. (1992), Theology and the Option for the Poor. Michigan: A Michael Glazier

obulondekhana bwo obwibulani. Butere: AICMA Publishers.

Ochilo, M. R. (2005), The Church of God Trumpets. Kisumu: National Printing Press.

Ogot, B. A. (1999), Building on the Indigenous; Selected Essays 1981 - 1998. Nairobi: Regal

Pope Paul VI. (1993), Populurum Progressio. Washington DC: Catholic Conference.

Prandervand, P. (1990), Listening to Africa; Developing Africa from the Grass Roots. New Press Publishers.

Readings on Poverty, Politics and Development. Institute of Population Studies: Anderson University Press.

Saitoti, G. (2002), Economic Development. Nairobi: Government Printers.

Sinclair, M. (1980), Green Finger of God. Cape Town: Oxford University Press.

Stafford, W. L. (2000), Church of God at the Crossroads. Anderson: Warner Press

Tarino, A. S. (2005), Applied Ethics and Africa's Social Reconstruction. Nairobi: Acton Publications.

Tarino, A. S. (2005), Applied Ethics and Africa's Social Reconstruction. Nairobi: Acton Publications.

Zacharia, G. (2007), Participation of Women in Development in Rural Areas in Kenya: Readings on Poverty, Politics and Development. Institute of Population Studies: Anderson University Press. 